\title{
SEBARAN ALTERASI BATUAN BERDASARKAN RASIO Th/U DI TAPALANG, MAMUJU, SULAWESI BARAT
}

\author{
DISTRIBUTION OF ROCK ALTERATION BASED ON TH/U RATIO IN \\ TAPALANG, MAMUJU, WEST SULAWESI
}

\section{Gde Sukadana, Frederikus Dian Indrastomo, Ngadenin}

Pusat Teknologi Bahan Galian Nuklir, BATAN, Jl. Lebak Bulus Raya No. 09, Jakarta, 12440

\begin{abstract}
ABSTRAK Kecamatan Tapalang, Mamuju, menjadi tujuan eksplorasi uranium dengan adanya radiasi tinggi terdeteksi pada batuan basaltik Formasi Adang. Diperlukan lokalisasi daerahdaerah dengan tingkat potensi kandungan uranium yang tinggi. Proses alterasi meningkatkan tingkat kelarutan uranium, sehingga kadar uranium berkurang dan terjadi pengkonsentrasian torium serta logam tanah jarang (REE) yang signifikan. Dengan asumsi bahwa alterasi berasosiasi dengan rasio $\mathrm{Th} / \mathrm{U}$, maka dilakukan penelitian untuk mengetahui sebaran alterasi batuan berdasarkan korelasinya terhadap rasio $\mathrm{Th} / \mathrm{U}$. Penelitian dilakukan dengan pengukuran radioaktivitas dan pengamatan alterasi di lapangan, kemudian dilengkapi dengan analisis XRF dan analisis mineragrafi untuk mengetahui tingkat alterasi. Rasio Th/U pada batuan lava Tapalang yang masih relatif segar memiliki nilai 3-30, dan batuan yang telah teralterasi memiliki nilai $30->3000$. Pengembangan eksplorasi torium dapat difokuskan pada daerah dengan alterasi lanjut, sedangkan eksplorasi uranium harus difokuskan pada daerah yang bersifat reduktif, yang memungkinkan terbentuknya cebakan uranium.
\end{abstract}

Naskah masuk : 2 Februari 2018

Naskah direvisi : 17 Mei 2018

Naskah diterima : 23 Juli 2018

I Gde Sukadana

Pusat Teknologi Bahan Galian Nuklir, BATAN, Jl. Lebak Bulus Raya No. 09, Jakarta, 12440

Email : sukadana@batan.go.id
Kata kunci: Rasio $\mathrm{Th} / \mathrm{U}$, alterasi, torium, uranium, Mamuju.

ABSTRACT Tapalang, Mamuju, is a destination for uranium exploration due to the high radiation detected in basaltic rocks of Adang Formation. Uranium potentials localization is required since uranium is not distributed evenly. An alteration process increases the level of uranium solubility, so that the uranium content is depleted and the concentration of thorium and rare earth elements (REE) are significantly high. This study objective was to find the distribution of rock alterations and their correlation to the ratio of $T h / U$ in Tapalang Region. Research methods were combination of radioactivity measurement and alteration observation in the field, completed by XRF and mineragraphy analysis to measure the grade of alteration. The alteration product indicated that this area has been affected by hydrothermal alteration in the potassic zone. Th/U ratio of fresh Tapalang lava rocks has a value of 3-30, and alterated rocks have 30 - 3000 value. These values can be used to delineating alteration areas, which have high $T h / U$ ratio $(30$ - >3000). The development of thorium exploration can be focused on advanced alteration areas, whereas uranium exploration should focus on reductive areas that allow for uranium deposited.

Keywords: Th/U ratio, alteration, thorium, uranium, Mamuju.

\section{PENDAHULUAN}

Kawasan Mamuju telah dipelajari secara intensif untuk eksplorasi uranium sejak 2013 (Sukadana \& Syaeful, 2016). Penelitian dimulai saat tingkat dosis radioaktivitas tinggi diukur di daerah tersebut. Tingkat dosis direkam sampai 2.800 $\mathrm{nSv} / \mathrm{h}$ (Iskandar, et al., 2014). Radiasi terdeteksi dari batuan dan tanah dalam distribusi batuan 
basaltik Formasi Vulkanik Adang, dan diklasifikasikan sebagai bahan radioaktif alami (NORM). Kadar torium (Th) yang signifikan dijumpai di beberapa daerah di Tapalang. Pada tempat yang berbeda memiliki kadar Uranium yang tinggi, yang menyebabkan nilai laju dosis radiasi $>5 \mathrm{mSv} /$ tahun. Sebaran daerah dengan laju dosis tinggi ditunjukkan pada Gambar 1 (Syaeful, et al., 2014).

Berdasarkan penyelidikan geologi yang lebih rinci, tingkat dosis radiasi tinggi hanya terdistribusi di kompleks vulkanik Adang, Ampalas, Tapalang, dan Malunda. Sementara pada vulkanik Sumare, Labuanrano dan Karampuang memiliki radiasi lebih rendah (Sukadana, et al., 2015). Jenis batuan vulkanik di Mamuju memiliki kandungan $\mathrm{K}_{2} \mathrm{O}$ tinggi, yang terbentuk pada tataan tektonik batas kontinen aktif (Active Continental Margin - ACM) (Sukadana, et al., 2015). Daerah ini memiliki karakteristik yang berbeda dari batuan vulkanik radioaktif lainnya seperti di daerah Kawat, Kalimantan Timur, dimana batuan ryolitik, memiliki konsentrasi $\mathrm{K}_{2} \mathrm{O}$ yang lebih rendah (Ngadenin, et al., 2011).

Keterdapatan uranium dan torium pada batuan vulkanik di daerah Tapalang dikontrol oleh sebaran jenis batuan dan tanah penyusunnya. Mineral utama yang mengandung uranium dan torium adalah davidite dan thorianite. Sementara mineral sekunder diidentifikasi sebagai gummite dan autunite (Sukadana, et al., 2015). Pengayaan mineral radioaktif terjadi karena beberapa aktivitas vulkanik di daerah Mamuju. Hal tersebut diperkuat dengan analisis penginderaan jauh yang menunjukkan banyaknya fitur melingkar di daerah Mamuju dan ditafsirkan sebagai pusat kegiatan vulkanik, termasuk daerah Tapalang (Indrastomo, et al., 2016). Daerah yang memiliki kadar torium tinggi umumnya memiliki tingkat alterasi batuan yang tinggi dengan rasio $\mathrm{Th} / \mathrm{U}$ sangat bervariasi (Condomines, et al., 2007), sehingga perlu dilakukan korelasi antara sebaran alterasi batuan dengan rasio $\mathrm{Th} / \mathrm{U}$ pada daerah penelitian.

\section{Geologi dan Rasio Kadar Th/U}

Daerah Tapalang secara umum tersusun atas breksi lava Tapalang (Brkst), lava Ahu (Lvah), dan lava Takandeang (Lvtkd) berkomposisi ponolitik dan foiditik. Sebagian lagi tersusun atas batugamping kristalin Formasi Mamuju (Btgp), endapan sungai $(\mathrm{Qb})$, dan endapan aluvial $(\mathrm{Qa})$
(Sukadana, et al., 2015). Peta Geologi daerah penelitian dapat dilihat pada Gambar 2. Batuan yang memiliki nilai potasium yang tinggi akan memiliki korelasi yang positif terhadap meningkatkan kadar uranium dan torium secara alamiah (Burwash \& Cavell, 1978). Secara alamiah rasio torium dan uranium pada batuan beku plutonik berkisar antara 2 sampai 5,5. Sedangkan pada batuan gunung api, rasio $\mathrm{Th} / \mathrm{U}$ berkisar antara 2,6 sampai 3,2 seperti terlihat pada Tabel 1 (Larsen \& Gottfried, 1960). Batuan vulkanik memiliki rasio $\mathrm{Th} / \mathrm{U}$ yang cukup konstan, sedangkan pada batuan granitik terjadi proses pengkayaan uranium dan torium melalui proses diferensiasi magma (Burwash \& Cavell, 1978; Larsen \& Gottfried, 1960).

Batuan di Daerah Tapalang memiliki komposisi alkalin dan kaya akan leusit. Batuan ini memiliki kandungan uranium dan torium yang lebih tinggi. Hal ini disebabkan oleh meningkatnya kandungan Potasium (K) dalam batuan. Peningkatan kadar U dan Th pada batuan alkaline bersifat stabil, sehingga akan memiliki rasio yang relatif konstan (Burwash \& Cavell, 1978). Terjadinya perubahan rasio yang signifikan terjadi akibat alterasi kloritisasi, karena proses tersebut akan melarutkan uranium yang cukup signifikan, sehingga rasio $\mathrm{Th} / \mathrm{U}$ akan terus meningkat (Kim, et al., 2017). Pelarutan uranium yang cukup signifikan menyebabkan torium terakumulasi pada bagian yang teralterasi kuat. Berdasarkan kondisi tersebut, dapat diketahui hubungan antara tingkat alterasi dalam batuan dan rasio U/Th.

\section{METODE}

Untuk mengetahui korelasi antara tingkat alterasi batuan dengan rasio $\mathrm{Th} / \mathrm{U}$, maka dilakukan serangkaian kegiatan pendataan lapangan dan uji laboratorium. Lokasi survey adalah Kecamatan Tapalang, Mamuju (Gambar 1). Kegiatan lapangan yang dilakukan adalah pemetaan alterasi batuan untuk mengetahui tingkat dan sebaran alterasi batuan. Juga dilakukan pengukuran radioaktivitas tanah dan batuan menggunakan RS 125 yang dapat mengukur radionuklida $\mathrm{U}$,Th dan K. Hasil pengukuran merupakan sumber data yang digunakan untuk menghitung rasio $\mathrm{Th} / \mathrm{U}$. Selanjutnya, dilengkapi dengan analisis XRF di PTBGN-BATAN untuk mengetahui kadar unsur, terutama $U$ dan $T h$. Pengamatan mineral dan alterasi batuan juga dilakukan dengan pembuatan sayatan tipis (petrografi). 


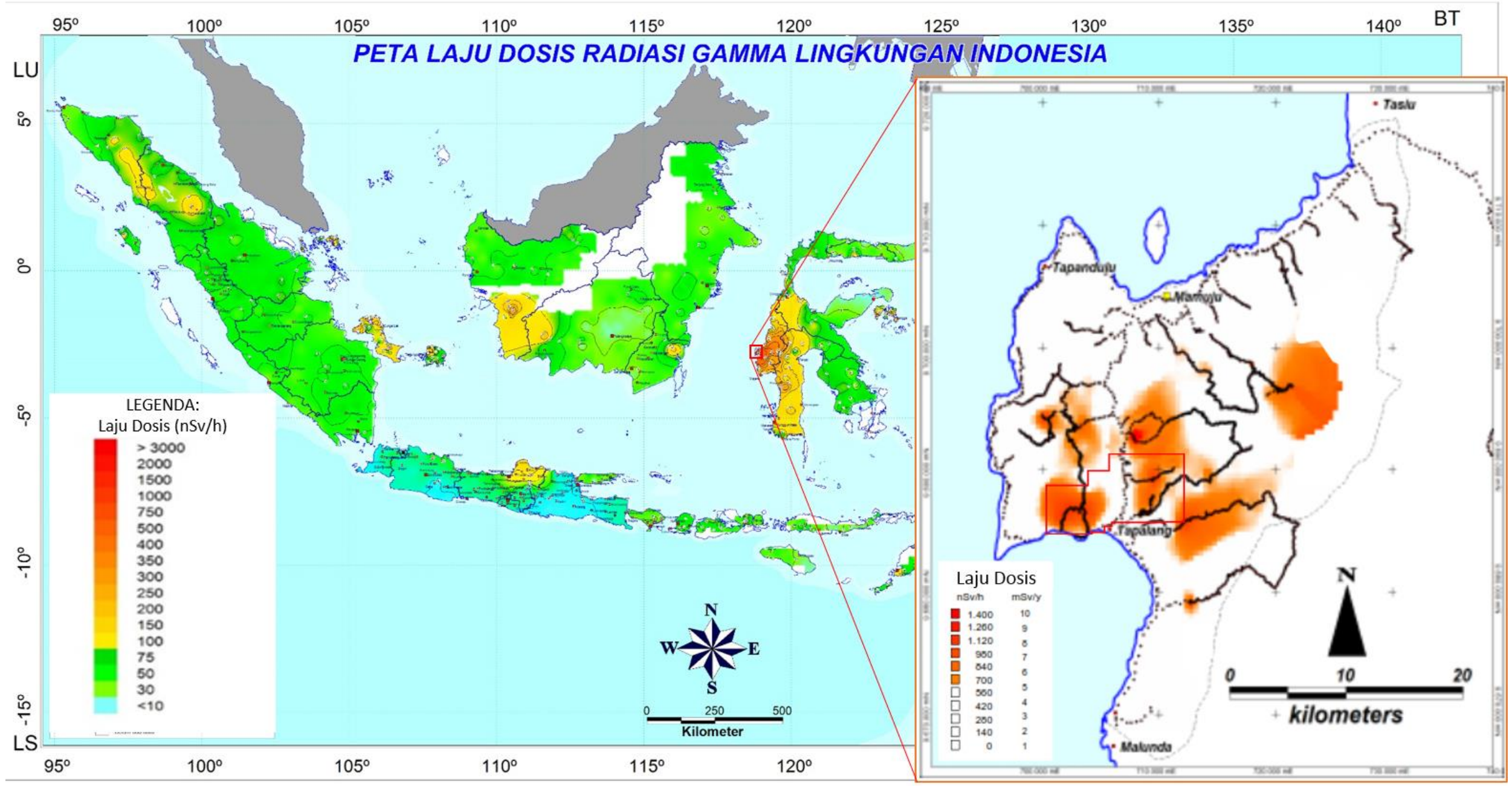

Gambar 1. Daerah yang memiliki laju dosis $>5 \mathrm{mSv} /$ tahun (Syaeful et al., 2014). Lokasi penelitian ditandai dengan batas poligon biru. 


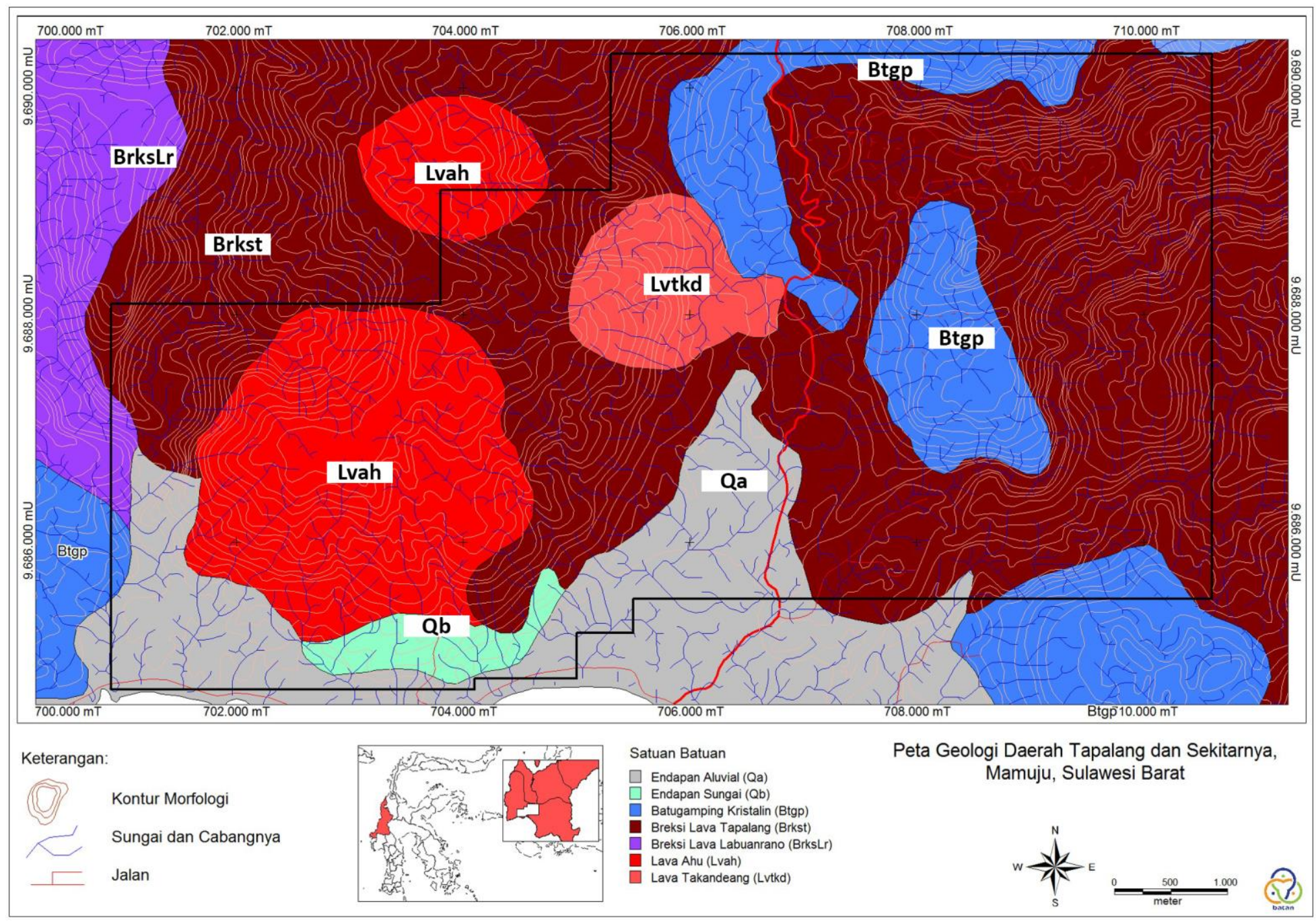

Gambar 2. Peta Geologi Daerah Tapalang dan sekitarnya, Mamuju, Sulawesi Barat (Sukadana, et al., 2015). 
Tabel 1. Nilai kadar U, Th dan rasio Th/U pada batuan di gunung api Hawaii dan batuan beku plutonik dari California selatan (Larsen \& Gottfried, 1960).

\begin{tabular}{llllllll}
\hline \multirow{2}{*}{ Lokasi } & \multirow{2}{*}{$\begin{array}{l}\text { Jumlah } \\
\text { sampel }\end{array}$} & \multicolumn{2}{c}{ Uranium $(\mathbf{p p m})$} & \multicolumn{2}{c}{ Torium (ppm) } & \multicolumn{2}{c}{ Rasio Th/U } \\
\cline { 3 - 8 } & & Nilai & Rerata & Nilai & Rerata & Nilai & Rerata \\
\hline Koolau volkanik*) & 7 & $0,27-0,54$ & 0,32 & $0,2-0,9$ & 0,79 & $1,8-4,5$ & 2,6 \\
Mauna Loa, *) & 7 & $0,21-0,28$ & 0,25 & $1,4-8,2$ & 0,80 & $2,3-4,1$ & 3,2 \\
Kilauea, $\left.{ }^{*}\right)$ & 9 & $0,28-0,41$ & 0,35 & $0,84-1,4$ & 1,1 & $2,6-3,5$ & 3,1 \\
Gabro **) & 7 & $0.17-0.40$ & 0,3 & $0,2-0,9$ & 0,6 & $0,7-4,7$ & 2,4 \\
Tonalit, & 12 & $0.6-2,8$ & 1,3 & $1,4-8,2$ & 4,1 & $0,9-7,5$ & 3,3 \\
Granodiorit **) & 24 & $1,2-4,2$ & 2,0 & $3,1-15,2$ & 7,8 & $2,2-6,5$ & 4,2 \\
$\begin{array}{l}\text { Quartz Monzonite } \\
\text { dan granit **) }\end{array}$ & 2 & $5,2-5,3$ & 5,2 & $16,0-22,2$ & 19,1 & $3,0-4,3$ & 3,7 \\
$\begin{array}{l}\text { Muscovite - Quartz } \\
\text { monzonite**) }\end{array}$ & 1 & & & & & & \\
\hline
\end{tabular}

\section{Pengukuran Radiometri}

Secara alamiah, terdapat berbagai sumber radiasi di alam. Potassium, uranium, dan torium meluruh dan memancarkan radiasi gamma, yang dapat terdeteksi oleh detektor gamma survei meter. Pada batuan yang terbentuk di kerak benua, secara alamiah memiliki kandungan potasium (K) 1 $2,5 \%$, uranium (U) $2-3 \mathrm{ppm}$, dan torium $(\mathrm{Th}) 8-$ 12 ppm. Ketidaksetimbangan $\mathrm{K}$, U, dan Th merupakan reaksi alamiah yang dapat menimbulkan energi. Pancaran energi sinar gamma dari $\mathrm{K}$ dideteksi dari pancaran energi sebesar 1,461 MeV yang merupakan hasil peluruhan ${ }^{40} \mathrm{~K}$. Energi yang digunakan untuk mendeteksi uranium sebesar $1,765 \mathrm{MeV}$ yang dipancarkan oleh anak luruhnya ${ }^{214} \mathrm{Bi}$, sedangkan torium diukur dari energi yang dipancarkan oleh ${ }^{208} \mathrm{Tl}$ sebesar 2,615 MeV (Tabel 2) (IAEA, 2003). Pengukuran ini dapat dilakukan secara menerus ataupun statik. Hasil pengukuran radiometri dengan RS 125 akan menghasilkan nilai cacah berupa nilai cacah gamma (cps), nilai laju dosis radiasi $(\mathrm{Sv} / \mathrm{h})$, kadar potassium $(\% \mathrm{~K})$, kadar uranium (ppm eU) dan kadar torium (ppm eTh).
Tabel 2. Standard gamma ray energy windows yang digunakan dalam memetakan radioelemen alam (IAEA, 2003).

\begin{tabular}{lcc}
\hline \multicolumn{1}{c}{ Jendela } & Nuklida & $\begin{array}{c}\text { Kisaran Energi } \\
(\mathrm{MeV})\end{array}$ \\
\hline Total Count & - & $0,400-2,810$ \\
Potassium & ${ }^{40} \mathrm{~K}(1,460 \mathrm{MeV})$ & $1,370-1,570$ \\
Uranium & ${ }^{214} \mathrm{Bi}(1,765 \mathrm{MeV})$ & $1,660-1,860$ \\
Torium & ${ }^{208} \mathrm{Tl}(2,614 \mathrm{MeV})$ & $2,410-2,810$ \\
\hline
\end{tabular}

Dalam penelitian ini, pengukuran radiometri dilakukan dengan menggunakan spektrometer gamma tipe RS 125, dengan spasi jalur pengukuran (grid) $200 \mathrm{~m}$ dan $50 \mathrm{~m}$ (Gambar 3). Pengukuran dilakukan dengan metode dinamis, sehingga didapatkan nilai kadar K (\%), ekuivalen $\mathrm{U}$ (ppm eU), dan ekuivalen Th (ppm eTh). Hasil pengukuran selanjutnya diolah menggunakan statistik sederhana untuk mendapatkan nilai latar dan anomali kadar, serta dilakukan penggambaran peta iso kadar eU dam eTh. Selanjutnya, rasio $\mathrm{Th} / \mathrm{U}$ dihitung serta dibuat peta distribusinya. 


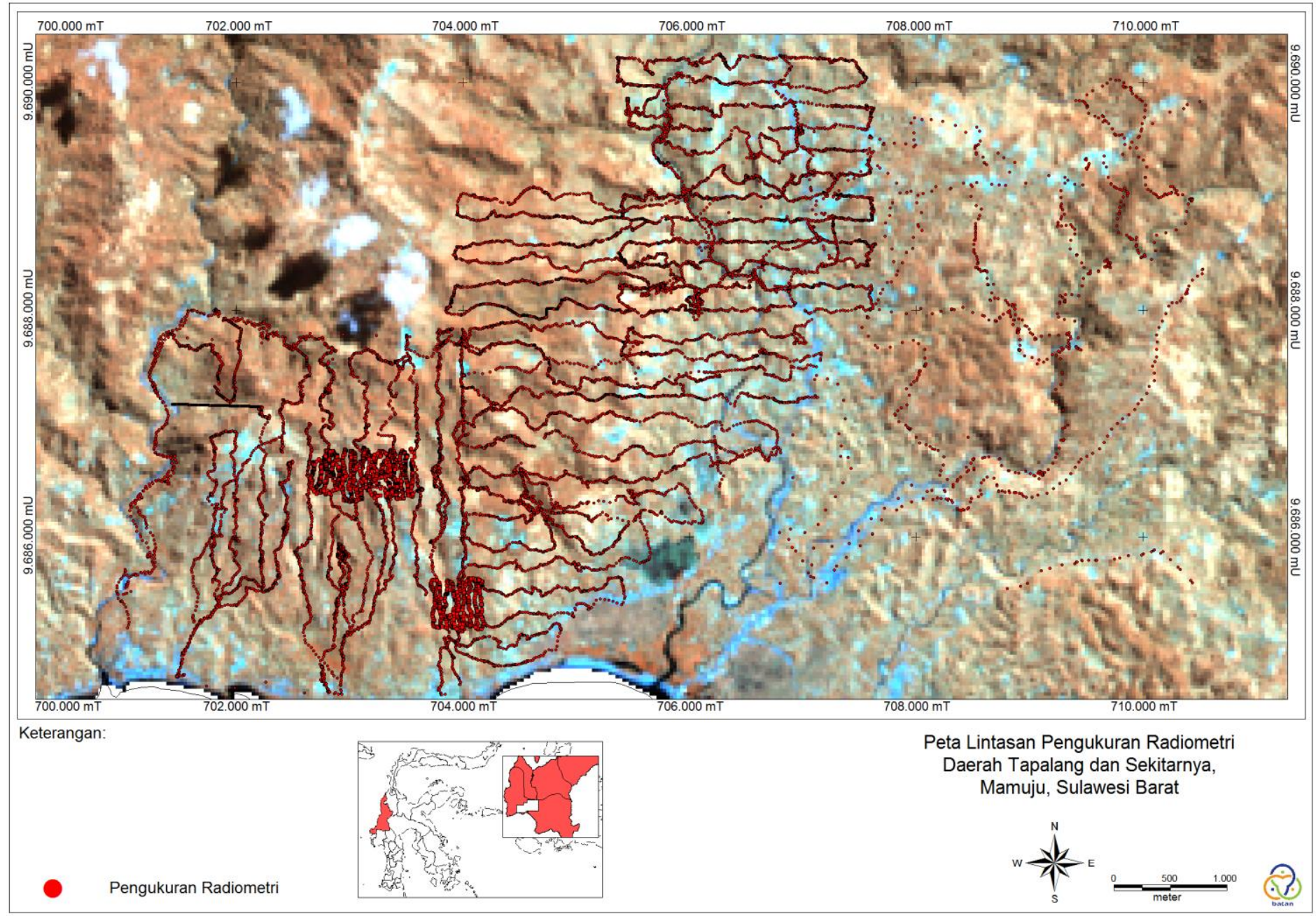

Gambar 3. Lokasi dan lintasan pengukuran radiometri dengan Gamma spektrometer RS 125. 
Pengamatan alterasi dilakukan dalam pemetaan lapangan sepanjang lintasan pengukuran radiometri. Selain mengamati ketebalan alterasi, observasi singkapan, dan deskripsi mineralogi batuan terubah. Pada kegiatan ini juga dilakukan pengukuran ketebalan, dan pengambilan contoh batuan teralterasi yang dilakukan pada lubang pemboran. Selanjutnya batuan teralterasi digunakan untuk analisis petrografi.

Analisis kimia dengan $X$-ray Fluoresence (XRF) dilakukan untuk mengetahui kadar oksida utama, U, Th dan Logam Tanah Jarang (LTJ) pada batuan yang segar dan batuan teralterasi.

\section{HASIL DAN PEMBAHASAN}

\section{Radiometri}

Pengukuran radiometri dilakukan pada sejumlah 26.164 titik. Masing masing titik memiliki koordinat $\mathrm{X}, \mathrm{Y}$ dan $\mathrm{Z}$ serta besaran radionuklida yang terukur, yaitu $\% \mathrm{~K}$, ppm eU dan ppm eTh. Selanjutnya seluruh data tersebut diolah dengan menggunakan statistik sederhana, untuk mendapatkan sebaran data, anomali serta daerah yang potensial. Selanjutnya dilakukan penggambaran hasil statistik. Hasil pengukuran radiometri menunjukkan bahwa kadar $\mathrm{U}$ dan Th pada bagian permukaan yang sebagian besar telah berupa soil cukup signifikan. Hal ini menunjukkan tingginya kadar $\mathrm{U}$ dan Th pada batuan asalnya.

Berdasarkan tabel di atas, diketahui bahwa uranium memiliki nilai 0,0 hingga 556,3 ppm eU. Nilai rata-rata hasil pengukuran uranium adalah 26,88 ppm eU dan simpangan baku 30,81 ppm eU. Bila nilai latar terukur adalah 57,695 ppm eU dan dengan asumsi harga anomali adalah nilai latar ditambah $2 \mathrm{x}$ simpangan baku, maka nilai anomali yang didapat adalah 88,507 ppm eU. Hasil tersebut dituangkan ke dalam Peta Iso kadar uranium seperti Gambar 4.

Berdasarkan data pengukuran torium memiliki nilai 8,0 hingga $826,4 \mathrm{ppm}$ eTh. Nilai rata-rata hasil pengukuran uranium adalah $216,88 \mathrm{ppm}$ eTh dan simpangan baku 103,81 ppm eTh. Nilai anomali yang didapat adalah 423,016 ppm eTh. Hasil tersebut dituangkan ke dalam Peta Iso kadar uranium seperti Gambar 5.

Berdasarkan hasil pengukuran eU dan eTh, selanjutnya dilakukan pembuatan rasio $\mathrm{Th} / \mathrm{U}$. Nilai yang didapatkan dari pembuatan rasio ini berkisar antara 0 sampai 5.581. Nilai tersebut selanjutnya dibuat dalam peta Iso Rasio $\mathrm{Th} / \mathrm{U}$, dengan pembagian: $<1,1-3,3-30,30-300$ dan kelas 300->3000. Nilai rasio $<1$ umumnya dijumpai pada daerah yang mengalami mineralisasi uranium, dimana daerah ini memiliki kadar uranium lebih tinggi dari torium. Nilai rasio 1-3 dijumpai pada batuan yang tersingkap dalam kondisi segar. Nilai rasio 3-30 dijumpai pada daerah yang mengalami tingkat pelapukan sedang. Daerah dengan rasio diatas 30 telah mengalami perubahan yang sangat intensif dengan kenampakan lapangan seperti Gambar 6. Sebaran peta peta rasio $\mathrm{Th} / \mathrm{U}$ terdapat pada Gambar 7.

Hasil pemetaan radiometri permukaan, dengan rasio $\mathrm{Th} / \mathrm{U}$ yang sangat signifikan hingga lebih dari 3000, menunjukkan bahwa beberapa lokasi di Daerah Tapalang telah terjadi proses pelarutan uranium yang sangat intensif dan terjadi pengkayaan unsur torium. Hal ini dapat terjadi akibat adanya proses pelapukan, alterasi dan pencucian uranium oleh airtanah (Von Gunten, et al., 1999).

Tabel 3. Hasil pengukuran dengan RS-125.

\begin{tabular}{lllllllll}
\hline Table & Min & Max & Mean & $\begin{array}{c}\text { Simpangan } \\
\text { Baku }\end{array}$ & Latar & Anomali Jml Data \\
\hline U & 0,0 & 556,3 & 26,88 & 30,81 & 57,695 & 88,507 & 26.164 \\
Th & 8,2 & 826,4 & 216,83 & 103,09 & 319,924 & 423,016 & 26.164 \\
Th/U & 0,0 & 5581,0 & 17,43 & 77,289 & 94,720 & 172,009 & 26.164 \\
\hline
\end{tabular}


Sukadana et al / Sebaran Alterasi Batuan Berdasarkan Rasio Th/U di Tapalang, Mamuju, Sulawesi Barat

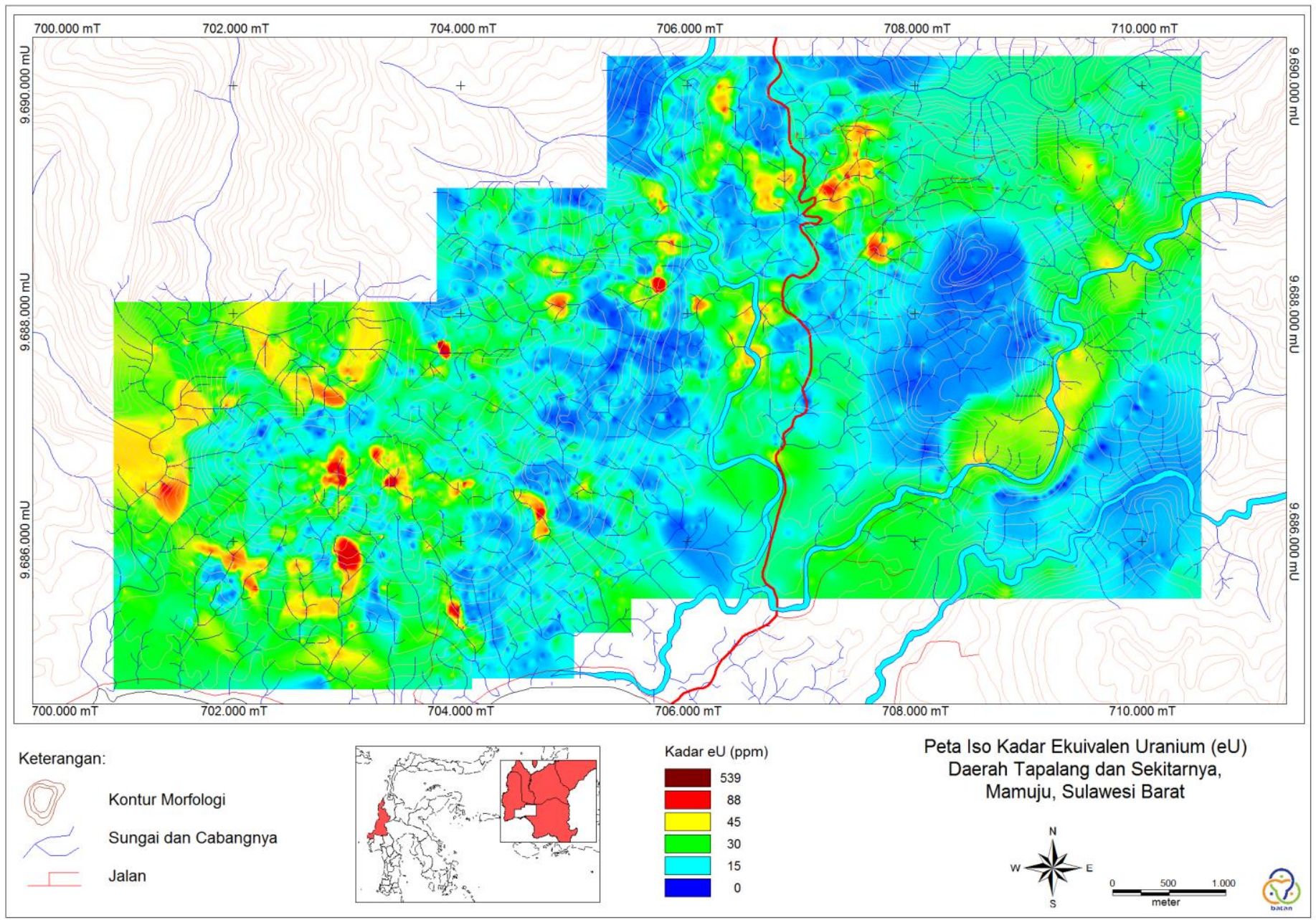

Gambar 4. Peta iso kadar uranium (eU) hasil pengukuran RS 125. 


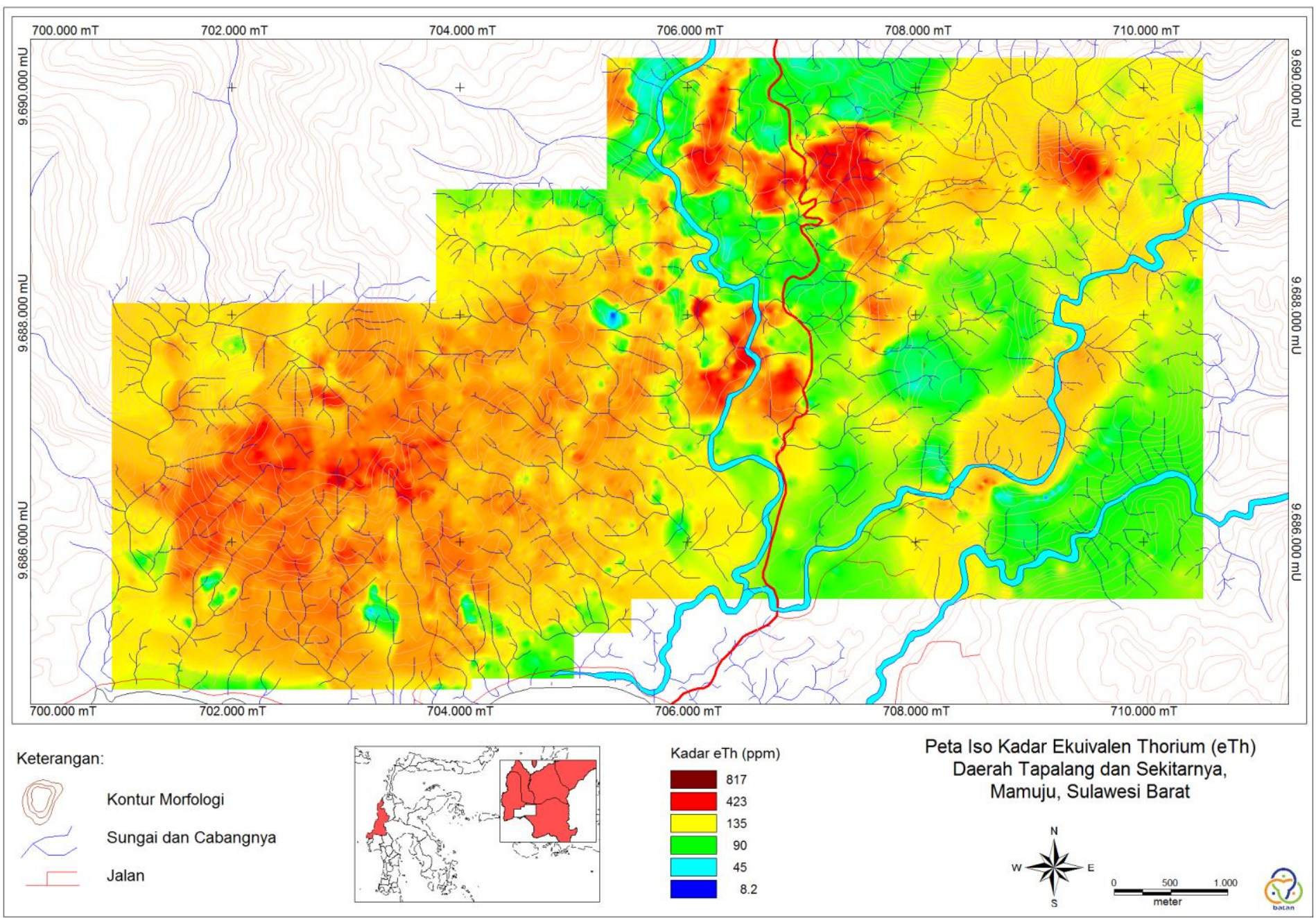

Gambar 5. Peta iso kadar torium (eTh) hasil pengukuran RS 125. 

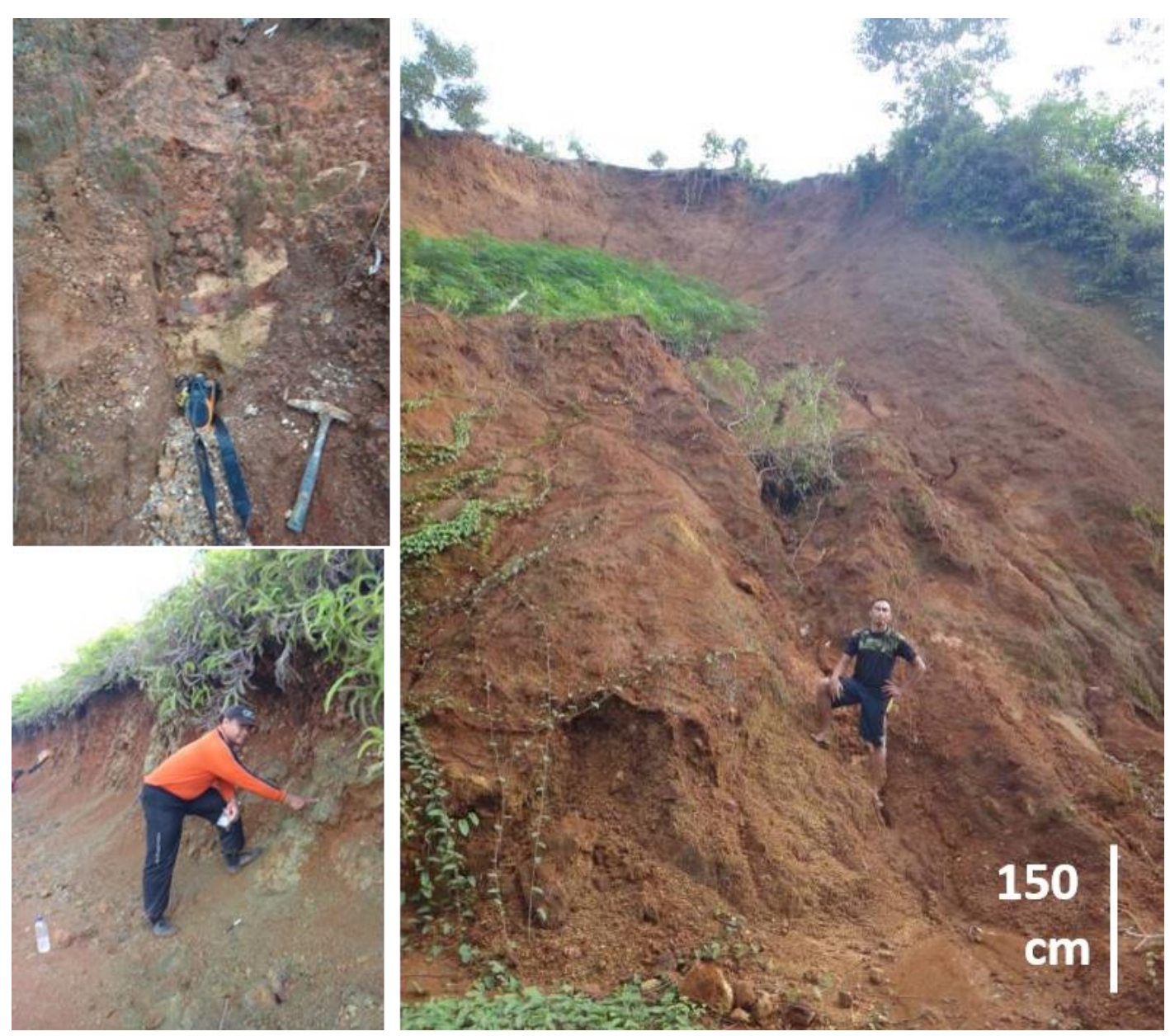

Gambar 6. Kenampakan alterasi batuan yang menjadi tanah tebal di Takandeang.

Tingginya rasio $\mathrm{Th} / \mathrm{U}$ menunjukkan bahwa uranium yang tercuci oleh air tanah belum dapat membentuk oksida uranium pada lokasi ini (Ballouard et al., 2017). Tidak terbentuknya oksida uranium disebabkan intensifnya proses alterasi hidrothermal yang terjadi. Proses hidrothermal ini ditunjukkan oleh munculnya kumpulan mineral ubahan seperti segregasi mineral biotit dan mineral lempung yang cukup tebal di lapangan, dan hadirnya mineral chlorite, actinolite, dan adularia pada beberapa sayatan tipis batuan. Komposisi mineral hasil alterasi seperti pada Gambar 8. Daerah dengan tingkat alterasi tinggi tampak memiliki ciri soil yang tebal (Gambar 6) dan sebaran yang cukup luas seperti Gambar 9. Produk alterasi tersebut menunjukkan bahwa daerah ini telah dipengaruhi oleh alterasi hidrothermal pada potassic zone.

Daerah yang memiliki nilai rasio $\mathrm{Th} / \mathrm{U}$ tinggi seperti di Daerah Takandeang, Orobatu dan Pasa'bu merupakan daerah dengan tingkat alterasi tinggi (intensif). Hal ini sangat menarik untuk pengembangan eksplorasi torium dan logam tanah jarang (Du, et al., 2012). Hasil analisis XRF pada dua sampel di daerah Takandeang, yang memiliki tingkat alterasi tinggi, menunjukkan kadar Th 1.000-1.200 ppm Th, kadar uranium 104-148 ppm $\mathrm{U}$, dengan kadar unsur logam tanah jarang (REE) total mencapai 1.815 ppm. Kondisi ini merupakan kondisi anomali bila dibandingkan dengan rasio kadar Th/U pada batuan segar(Larsen \& Gottfried, 1960).

Hasil pemetaan alterasi berdasarkan data rasio $\mathrm{Th} / \mathrm{U}$ menunjukkan bahwa daerah yang telah teralterasi tinggi memiliki rasio yang lebih tinggi. Pada zona alterasi telah terjadi deplesi atau pencucian uranium yang larut bersama larutan hidrothermal dan air tanah. Eksplorasi uranium dapat dikembangkan pada daerah yang lebih dalam atau daerah yang memiliki kondisi reduktif yang memungkinkan terbentuknya cebakan uranium oksida (Ohnuki et al., 2004). 


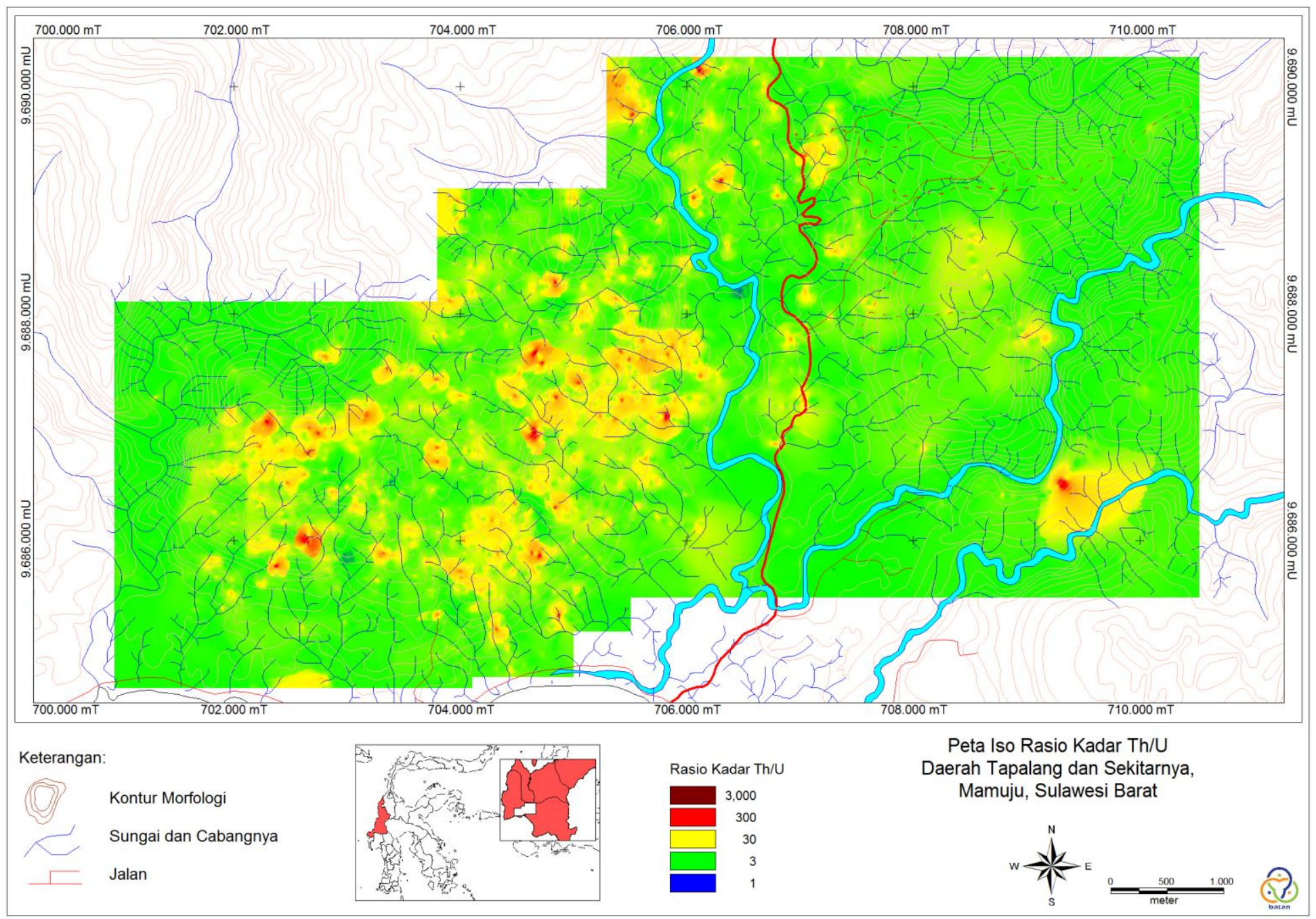

Gambar 7. Peta iso Th/U hasil pengukuran RS 125. 

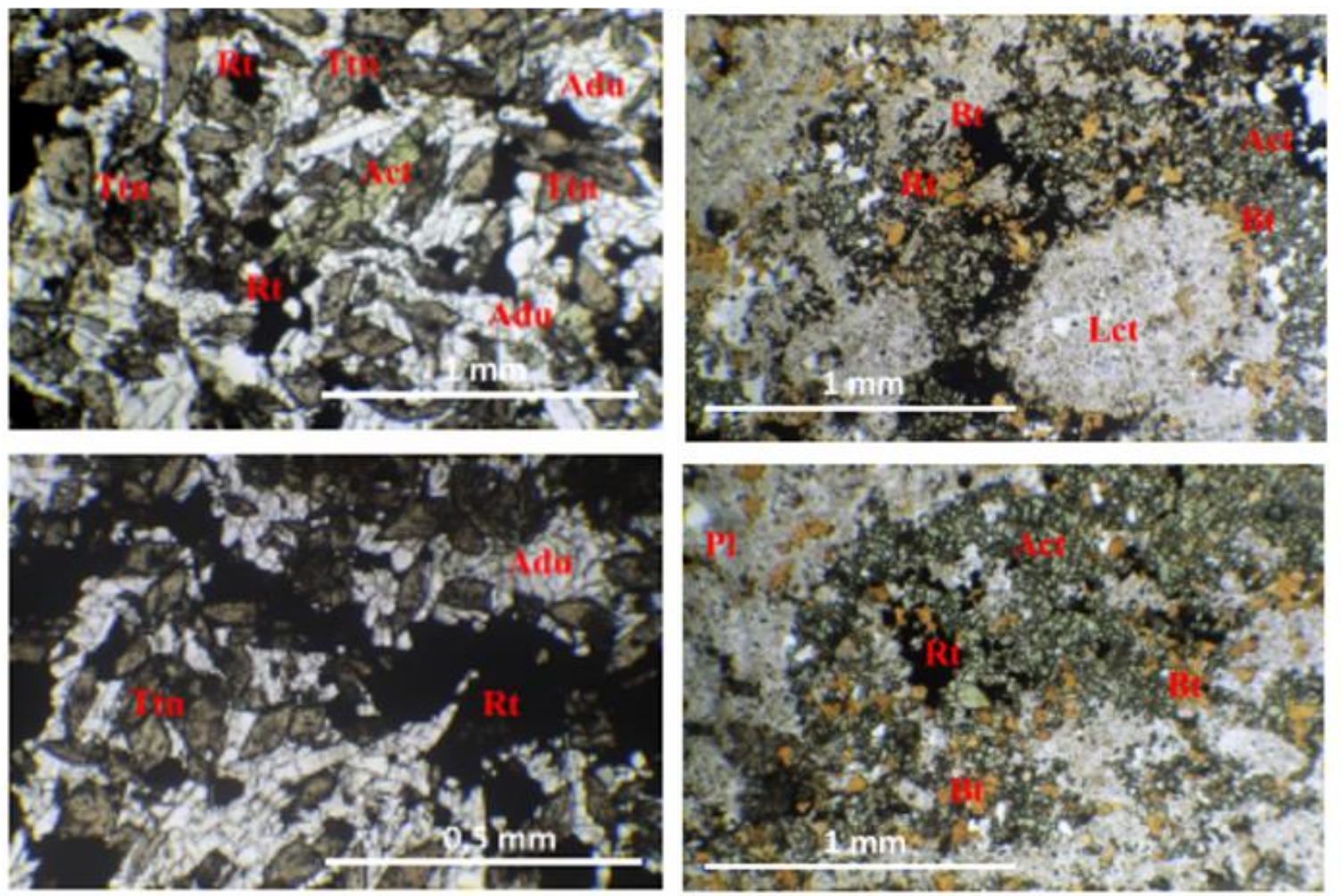

Ttn-Bt-Act-Adu Zone (potassic)
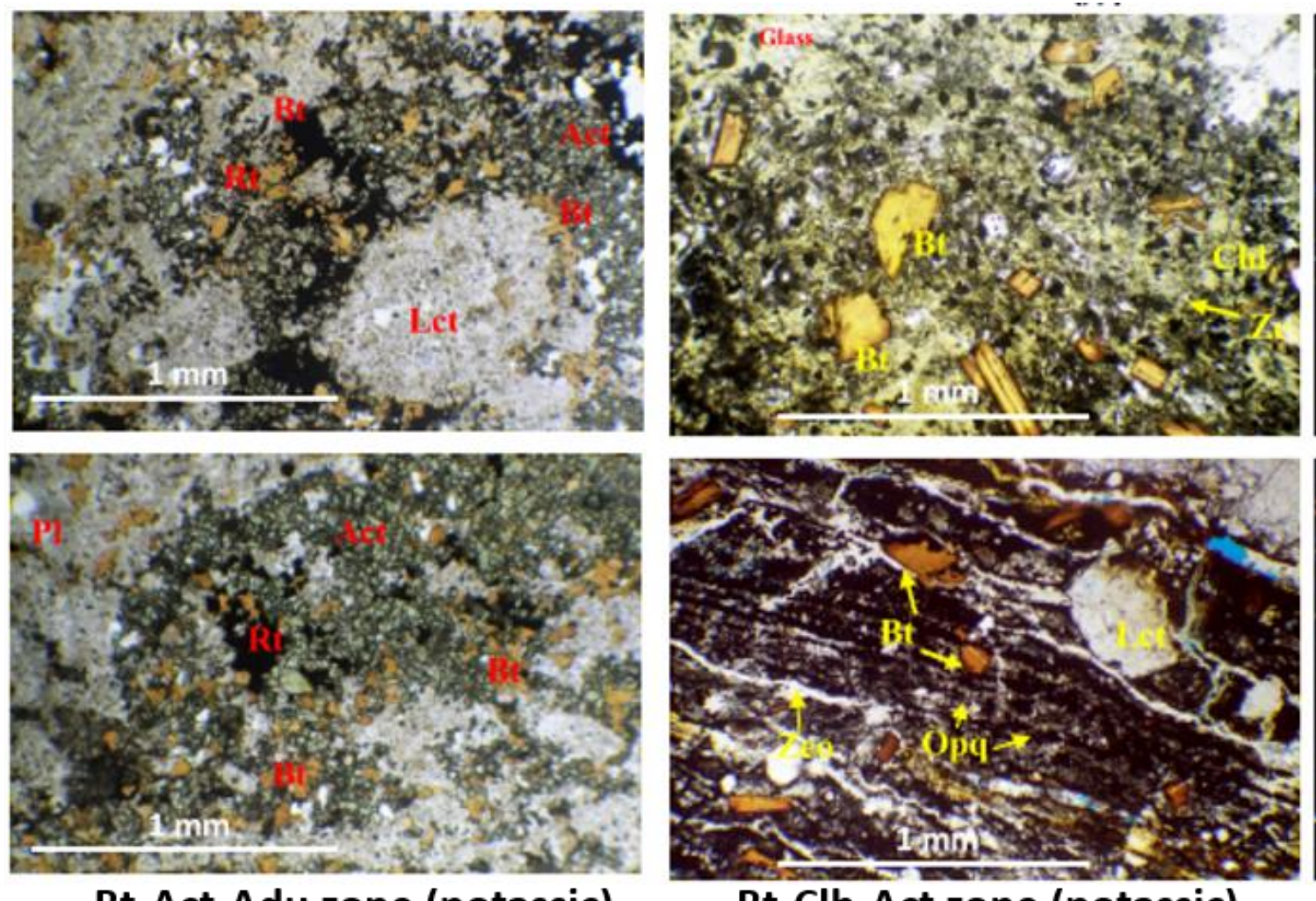

Gambar 8. Kumpulan mineral alterasi pada Sampel leucitite yang teralterasi dari contoh inti bor TKDK-1, TKDY 3 dan TKDK. 


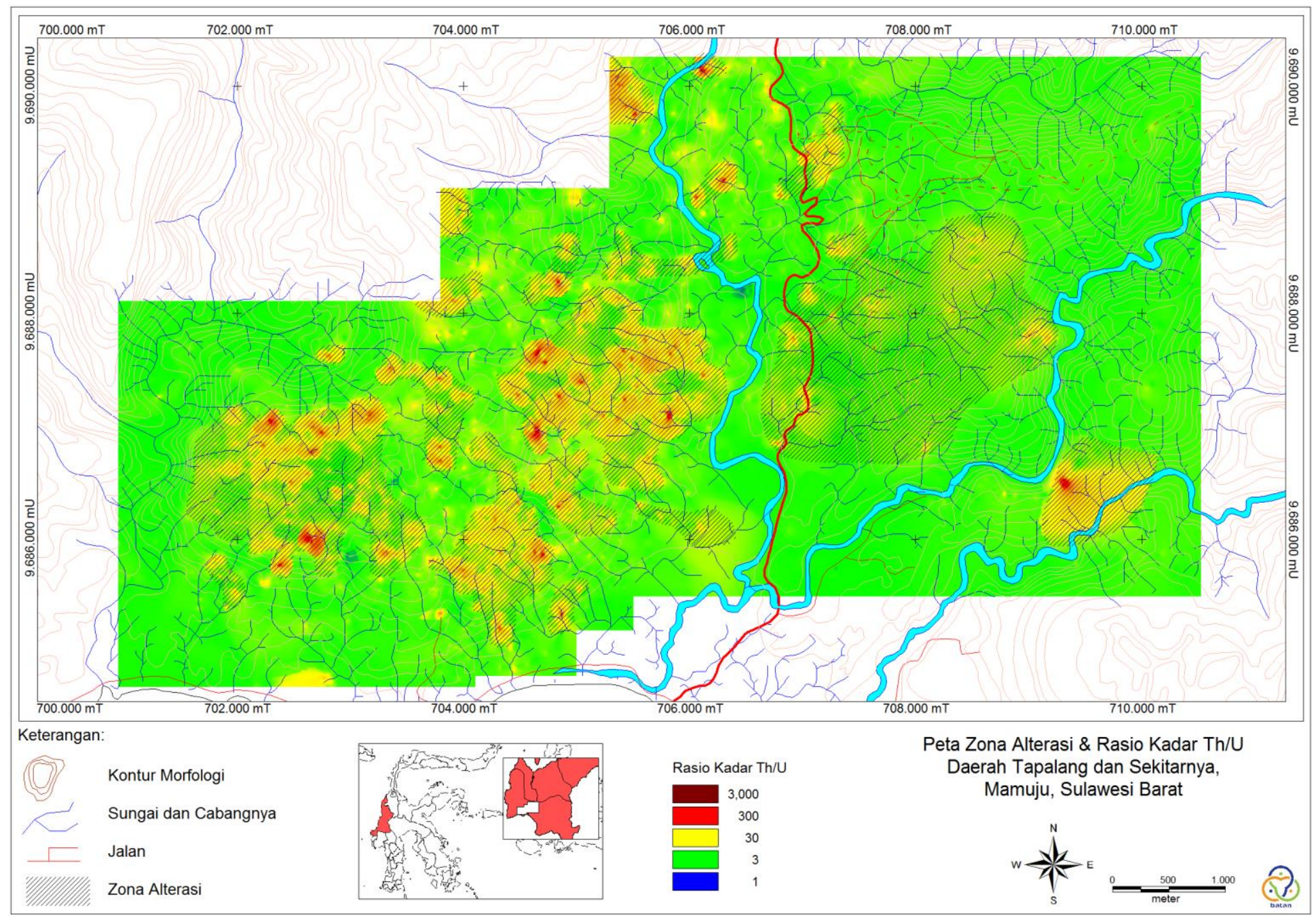

Gambar 9. Peta sebaran daerah alterasi yang berkorelasi dengan rasio U/Th. 


\section{KESIMPULAN}

Rasio $\mathrm{Th} / \mathrm{U}$ pada batuan lava Tapalang yang masih relatif segar memiliki nilai 3-30, dan batuan yang telah teralterasi memiliki nilai 30 hingga lebih dari 3000. Nilai tersebut dapat digunakan sebagai dasar dalam melakukan deleniasi daerah alterasi yang memiliki rasio Th/U tinggi (30 - >3000). Proses alterasi meningkatkan tingkat kelarutan uranium, sehingga kadar uranium telah mengalami depleted dan pengkonsentrasian torium serta logam tanah jarang (REE) yang signifikan. Pengembangan eksplorasi torium dapat difokuskan pada daerah alterasi lanjut, sedangkan eksplorasi uranium harus difokuskan pada daerah yang bersifat reduktif yang memungkinkan terbentuknya cebakan uranium.

\section{UCAPAN TERIMA KASIH}

Terima kasih kami sampaikan kepada Ir. Agus Sumaryanto, M.S.M. dan Heri Syaeful, MT., atas kesempatan yang diberikan dalam penelitian ini. Terima kasih juga kami ucapkan kepada Tim Mamuju, Rahmat Iswanto, Tukijo, Heri Prabowo dan tim pendukung lain yang memberi dukungan di lapangan ataupun laboratorium.

\section{DAFTAR PUSTAKA}

Ballouard, C., Poujol, M., Boulvais, P., Mercadier, J., Tartèse, R., Venneman, T., Cuney, M., 2017. Magmatic and hydrothermal behavior of uranium in syntectonic leucogranites: The uranium mineralization associated with the Hercynian Guérande granite (Armorican Massif, France). Ore Geology Reviews, 80, 309-331. DOI: 10. 1016/j.oregeorev.2016.06.034.

Burwash, R. A., dan Cavell, P. A. 1978. Contributions to Mineralogy and Petrology Uranium-Thorium Enrichment in Alkali Olivine Basalt Magma - Simpson Islands Dyke , Northwest Territories Canada. Contributions to Mineralogy and Petrology, $66,243-250$.

Condomines, M., Loubeau, O., dan Patrier, P. 2007. Recent mobilization of U-series radionuclides in the Bernardan $U$ deposit (French Massif Central). Chemical Geology, 244(1-2), 304-315. DOI: 10.1016/j.chemgeo.2007.06.020.

Du, X., Rate, A. W., dan Gee, M. A. M. 2012. Redistribution and mobilization of titanium, zirconium and thorium in an intensely weathered lateritic profile in Western Australia. Chemical Geology, 330-331, 101-115. DOI: 10.1016/j.chemgeo.2012. 08.030 .

IAEA. (2003). IAEA-TECDOC-1363: Guidelines for Radioelement Mapping Using Gammaray Spectrometry Data. Vienna: IAEA.

Indrastomo, F. D., Sukadana, I. G., Saepuloh, A., Harsolumakso, A. H., dan Kamajati, D. 2016. Volcanostratigraphy Interpretation of Mamuju Area Based on Landsat-8 Imagery Analysis. Eksplorium, 36(2), 71-88.

Iskandar, D., Syarbaini, dan Kusdiana. 2014. Map of Environmental Gamma Dose Rate of Indonesia. Jakarta: National Nuclear Energy Agency.

Kim, E., Ahn, H., Jo, H. Y., Ryu, J. H., dan Koh, Y. K. 2017. Chlorite alteration in aqueous solutions and uranium removal by altered chlorite. Journal of Hazardous Materials, 327, 161-170. DOI: 10.1016/ j.jhazmat. 2016.12.051.

Larsen, E., dan Gottfried, D. 1960. Uranium and thorium in selected suites of igneous rocks. American Journal of Science (US). Retrieved from http://www.osti.gov/ energycitations/product.biblio.jsp?osti_id= 4141929.

Ngadenin, Sukadana, I. G., Muhammad, A. G., dan Suripto. 2011. Inventarisasi Potensi Sumberdaya Uranium Daerah Kawat, Mahakam Hulu, Kalimantan Timur Tahapan Prospeksi Detil. Eksplorium, 32(2), 65-76.

Ohnuki, T., Kozai, N., Samadfam, M., Yasuda, R., Yamamoto, S., Narumi, K., ... Murakami, T. 2004. The formation of autunite (Ca(UO2)2 (PO4)2.nH2O) within the leached layer of dissolving apatite: Incorporation mechanism of uranium by apatite. Chemical Geology, 211(1-2), 1-14. DOI: 10.1016/j.chemgeo.2004.03.004.

Sukadana, I. G., Harijoko, A., dan Setijadji, L. D. 2015. Tectonic Setting of Adang Volcanic Complex in Mamuju Region, West Sulawesi Province. Eksplorium, 36(1), 3144. 
Sukadana, I. G., Indrastomo, F. D., dan Syaeful, H. 2015. Geology and Radionuclide Ratio Mapping For Radioactive Mineral Exploration in Mamuju, West Sulawesi. In Prosiding Seminar Nasional Teknologi Nuklir, pp. 140-147. Bali: PTKRN.

Sukadana, I. G., dan Syaeful, H. 2016. Uranium Exploration in Sulawesi. In Seminar on MGEI 8th Annual Convention 2016, pp. 117-120. Malang: MGEI.

Syaeful, H., Sukadana, I. G., dan Sumaryanto, A. (2014). Radiometric Mapping for Naturally Occurring Radioactive Materials (NORM) Assessment in Mamuju, West Sulawesi. Atom Indonesia, 40(1), 35. DOI: 10.17146/ aij.2014.263.

Von Gunten, H. R., Roessler, E., Lowson, R. T., Reid, P. D., dan Short, S. A. 1999. Distribution of uranium- and thorium series radionuclides in mineral phases of a weathered lateritic transect of a uranium ore body. Chemical Geology, 160(3), 225-240. DOI: 10.1016/S0009-2541 (99)00 062-5. 